\section{A Christmas story for the chairside}

\author{
(with profuse apologies to Charles Dickens)
}

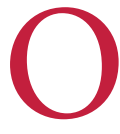

nce upon a time, many years ago, it was Christmas Eve. It was cold, bleak, biting weather and in the street outside the practice people went wheezing up and down, beating their hands on their chests and stamping their feet upon the paving stones to warm them. The town clock had only just gone three but it was dark already, it had hardly been light all day. Bunsen burners were flaring in the basement windows of a nearby dental laboratory like ruddy smears upon the palpable brown air.

Only Scrooge, Scrooge the dentist, Scrooge the miser, Scrooge the only remaining partner of Scrooge and Marley Associates, previous VT training practice, only he would not be celebrating Christmas in the usual way.

The last patient had just left, clutching a tissue to their mouth (their own tissue I hasten to add, Scrooge had all such wanton expenditure as free tissues under strict scrutiny) when in marched Scrooge's dental student nephew.

'A Merry Christmas Uncle', declared the youngster.

'Bah, gumbudge', said Scrooge, although he'd meant to say humbug.

'Christmas a humbug?' queried the nephew, sensing his uncle's lapse into dyslexia, 'surely you can't be serious?'

'How can I be anything else when I live in such a world of fools as Merry Christmas?

Every dental student who goes round with a

Merry Christmas on his lips should be cast in his own full coverage posterior crown with a sprig of holly through his cusp.'

The nephew, fresh from phantom head classes, took a gingival step backwards at the ferocity of his uncle's mood.

'I am sorry that you feel that way. Indeed while Christmas has never put a silver filling in my pocket or a golden inlay in my molar,' propounded the youth, somewhat mixing his metaphors and failing his restorative dentistry viva, 'I say good luck to it.'

Listening at the surgery door Scrooge's long suffering dental nurse Bobbi Cratchit started clapping involuntarily, and momentarily, as she caught Scrooge's look but dodged his flying flat plastic.

'One more sound from you and you'll celebrate Christmas by losing your situation, growled the old practitioner. 'You're quite an orator,' he turned back to the youngster. 'I wonder you don't go in for a place on the General Dental Council', he sneered.

Not to be deflected from his purpose the merry student continued unabashed, 'Do me one favour uncle', he pleaded, 'dine with my flatmates and me tomorrow.

'Humbug,' blustered Scrooge, recovering his composure.

'Well the offer remains. I can only hope that you'll change your mind.' With which the nephew bid them both the compliments of the season and departed into the snowy streets.

In doing so he had left the outside door ajar and in a moment there stood before Scrooge's rather dog-eared chair two prosperous looking gentlemen, beaming and showing their BDA membership cards.

'Mr Scrooge or Mr Marley?'

'Marley has been dead these seven years,' sneered Scrooge suspiciously.

'Very well Mr Scrooge, we will come straight to the point. We are collecting for the BDA Benevolent Fund. At this time of year it is always good to be able to offer some extra comforts to those less fortunate than ourselves. We wondered if we might put you down for a contribution.

'Have the health insurance companies gone bankrupt?' queried Scrooge.

'Not to my knowledge,' replied the other gentleman.

'And the social services are they closed for the festive season?' but....'

'Oh thank goodness,' said Scrooge sarcastically. 'I thought for a moment that my taxes were being misappropriated.

'So, what may we put you down for?'

'Nothing.' Scrooge narrowed his eyes which, seen through the loupes that he'd made from two children's magnifying glasses, made him look horrible to countenance.

'You wish to remain anonymous?' guessed one of the gentlemen.

'I wish, since you ask', said Scrooge, 'to be left alone. I do not make merry myself at Christmas and certainly have no inclination to give idle people money to make them merry'.

"But if they are "idle" through no fault of their own, interjected the plumper of the two men.

'Then I am sure it is no fault of mine either,' riposted Scrooge. 'Good day to you both.' So saying he scowled until they had left the premises.

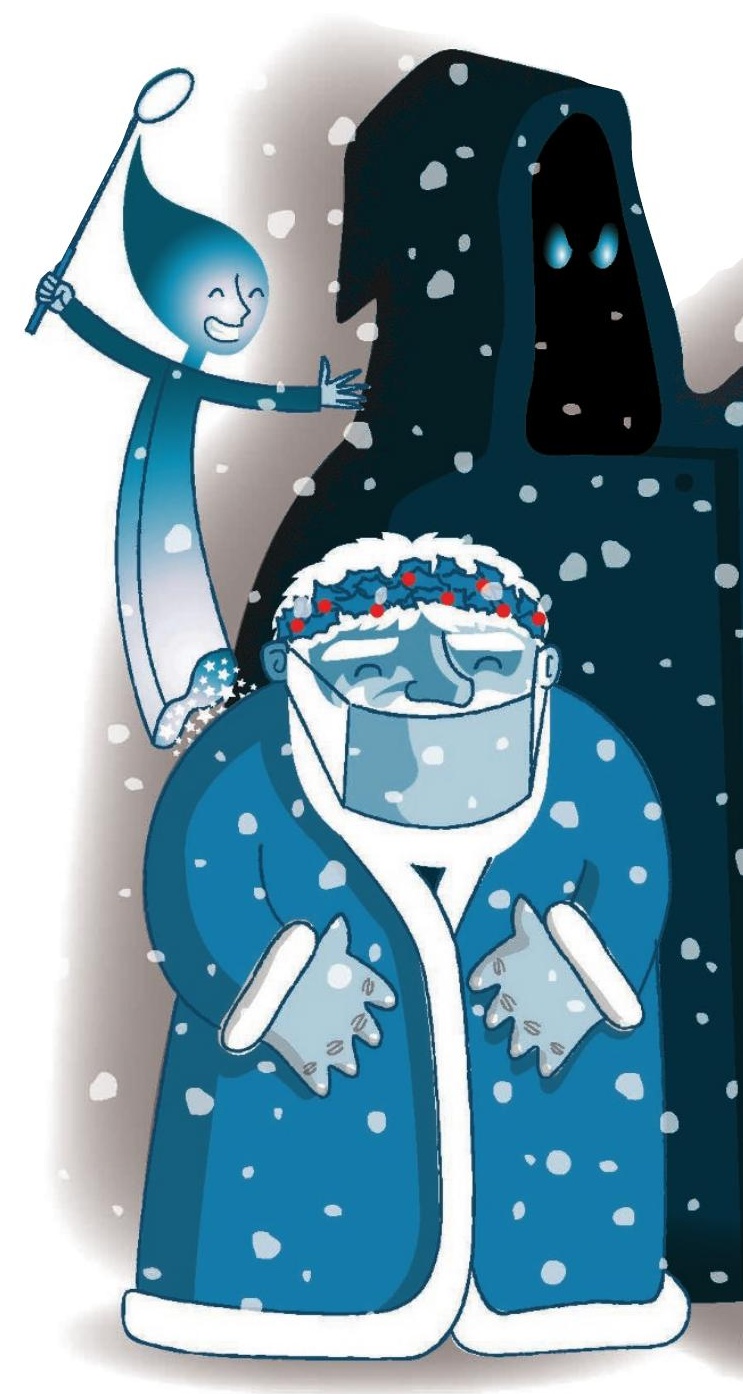


'I suppose you'll want the whole of tomorrow off?' questioned Scrooge as Bobbi Cratchit slipped on her poncho on her way out.

'It is only once a year', she said, as humbly as she could.

'A fine excuse to pick a man's periodontal pocket. Very well, but make sure you're extra early the following day.

Thoroughly disgruntled by being surrounded with such merriment, Scrooge went upstairs to his lonely rooms and put his ready to cook meal for one on the stove. It was part of a cheap batch he had bought from the grocer as it was beyond its sell by date. But it made no odds to Scrooge. Food was food. He had barely finished his portion of mutton ravioli when a strange noise caught his attention. It sounded as if all the instruments in the surgery below were jostling and jangling against one another. Gradually the noise became louder and it then sounded as if someone was coming up the stairs and into his flat.

'Not an emergency at this time of night surely', cursed Scrooge to himself.

But this was no patient. To Scrooge's horror and amazement straight through the door, literally, came the ghost of Jacob Marley, dragging behind him a

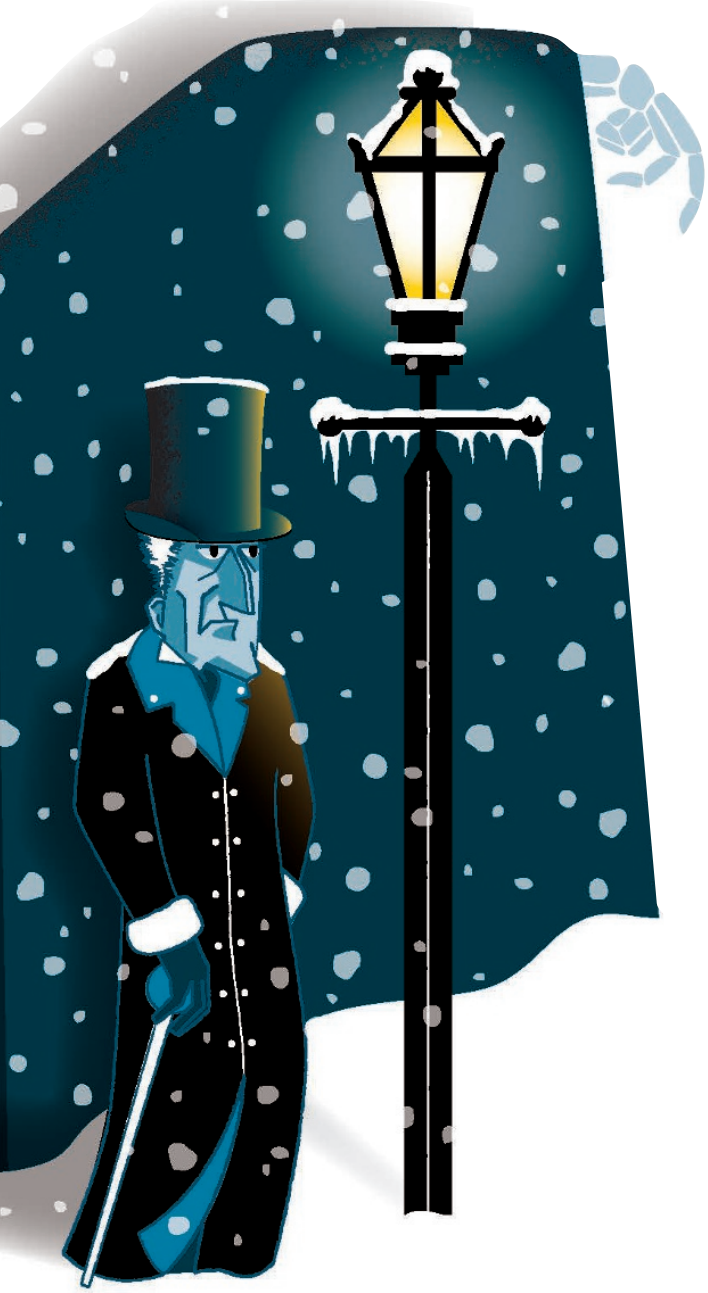

great chain, the links of which were made up of inlays and fillings, pontics, crowns and implant abutments which trailed all over the room.

'What are you doing here?' trembled Scrooge, 'and what is that chain you wear?'

'I am here to save you,' thundered Marley, 'this chain is the memory that I forged for myself during my life. I am doomed to entwined around them but there was only one lonely figure sitting in the corner waxing up a full gold crown.

Scrooge recognised himself immediately. He had been a keen student, regularly staying late and missing holidays just to improve on his quota and finish it sooner than any of his other colleagues. But seeing himself now he

\section{'It was clearly Christmas as the units had decorations entwined around them but there was only one lonely figure waxing up a full gold crown}

carry it with me where ever I go. Yours was quite twice as long and heavy as this seven years ago and you have laboured on it since with many UDAs, capitation schemes and private arrangements, it is now weighty and ponderous indeed.'

'But you were such a good man at business, Jacob.'

'Business? Consideration of the staff and the practice, customer care, the future of the profession, a little more generosity, those should have been my business,' boomed Marley's apparition.

'Is there nothing that can be done?' asked Scrooge, still numbed to a greater extent than his watered down local anaesthetics would have ever allowed.

'You will be visited by three spirits. Take note of what they have to show you and you may yet avoid the torment that I suffer. Now, I have to go. I have other duties to perform and I must not be late. I do not want to be charged for a missed appointment.'

'Quite so'. Scrooge understood only too well and was secretly wondering if he could claim Marley's visit as a domiciliary when the spectre groaned, as if having a troublesome eight removed and disappeared in a puff of dentine dust.

\section{The spirits}

After Marley's abrupt departure Scrooge fell into a deep sleep from which he was awakened by the presence of the diminutive figure of Practice Past.

'Quickly,' ordered the Spirit, 'we have much to see and do.'

Taking Scrooge by the hand the Spirit flew straight out of the window and the next he knew they had landed in the student clinic of Scrooge's old dental school. It was clearly Christmas as the units had decorations felt a sudden pang of loneliness.

Almost as if sensing his mood, the Spirit whisked him away to the waiting room of a dental practice where a party was obviously about to begin.

'Why this is old Fizziwig's practice,' said Scrooge, 'my first associateship was spent here.' Scrooge was transported back to the gaiety of the occasion as the practice team ate and drank, gossiped and danced until the friction from the nylon pile carpet gave them all static electricity shocks such that they had to collapse in laugher and exhaustion.

Scrooge beamed at the Spirit, 'Oh that was such fun and I remember it only cost us two pounds and five shillings each. So much pleasure for such a small sum.

The Spirit smiled.

Suddenly coming to, Scrooge was amazed to find himself back in his own bed. He looked at the watch he had got as a freebie by buying alginate mixing bowls in bulk.

'Checking-up on me huh?' beamed the Spirit of Practice Present as she bounded into the room. 'Get it? Checking-up, dentist. Oh never mind. Come on, no time to waste. Quick sticks'. And with this they were off again.

They swooped in low over the town and came to rest in a humble home. It was the Cratchit household and Bobbi Cratchit was sitting with Tiny Tim watching as he carved the most exquisite teeth out of miniature bars of soap.

'If only I could go to dental school,' sighed Tiny Tim, 'I know that being a one-parent family makes it tough Mum but am I really going to have to be an accountant instead?'

Bobbi gave a sad smile and ruffled the youngster's hair, marvelling at his mature outlook. 'Let's be happy, it's Christmas after all,' she merrily rejoined.

And happy they were. Despite their 
modest means the table was prepared with a handsome feast of turkey burgers and all the trimmings. A toast, cried Bobbi, to Christmas cheer and all it stands for.

'God fill us everyone, cheered Tiny Tim.

The Spirit couldn't be sure but thought she saw Scrooge wipe away a tear as they flew homewards.

'Good spirit, tell me that Tiny Tim won't have to become an accountant.'

'If these visions remain unchanged I see a calculator on the table and a tin of soapy teeth gathering dust in the chimney corner.'

The Spirit of Practice Yet To Come arrived in robes as black as a non-vital incisor, and, beckoning Scrooge to approach, revealed a flickering laptop screen shrouded beneath its cloak.

As the screensaver cleared, Scrooge beheld the portal to the practice swathed in mist of the desolate surgery was a pair of home made loupes.

\section{Marvellous morning}

Suddenly aware of light pouring in upon his bed, Scrooge, for some unaccountable reason, felt wonderfully alive. Leaping from the covers he headed straight for the window and threw up the sash.

'Hey, boy', called out Scrooge to a youth in the street below, 'what day is it today?'

The girl with the short haircut uttered an obscenity which previously would have incensed the old man but on this occasion only made him chuckle at his mistake as she told him in no uncertain terms that it was Christmas Day.

The marvellous Spirits had done their work all in one night. Everything lay before him and he could see it clearly now. In a

\section{'The Spirit of Practice Yet To Come arrived in robes as black as a non-vital incisor...'}

but with the door broken down and muddy footprints all down the hall and into the waiting room.

The reception desk, such as it was anyway, lay broken in pieces, record cards were strewn about the floor and the cash till ransacked and empty.

As the scene on the monitor changed so Scrooge saw that his surgery was stripped of equipment, bare wires protruded from ceiling, walls and sockets and underfoot, crushed boxes of filling materials were ground into the shabby linoleum. Then Scrooge gasped as a terrible sight caught his eye. There, smashed and broken in the corner trice he was down at the 24-hour supermarket snapping up the biggest turkey in the Festive Food Grotto and couriering it round to Cratchit Villas. Then he was off to his nephew's student hall of residence but, praise indeed he happened across the two gentlemen from the BDA Ben Fund.

'Gentlemen', he cried, 'what good fortune. Would you please put me down for...' and here he whispered confidentially.

'Well that is indeed most generous sir, are you sure?'

'I have never been more certain,' rejoined Scrooge and he skipped all the way to his nephew's.
If his nephew was amazed to see him, then it was as nothing compared with his delight at his uncle's participation in all the games they played, the stories they swapped and the agreement they reached about how much more fun dentistry would be if it wasn't for the patients!

Next morning Scrooge was up early again and in the surgery waiting for Bobbi. She arrived five minutes late.

'I'm so sorry to be late Mr Scrooge but yesterday the most extraordinary thing happened and...'

'And you thought that today couldn't possibly better it,' Scrooge ended her sentence but not at all in the way she had anticipated. 'Do you know the telephone number of the Dental Nurses Association?’ he queried.

'Why yes', stammered Bobbi, imagining she was going to be about to 'phone, from the call box around the corner (Scrooge was very particular about personal calls on the practice line) to find out about statutory dismissal.

'Then call and ask the top salary for dental nurses. Double it and that's your new rate for this year. We'll review it again on 1 January'.

Scrooge never told a soul about the Spirits. Who, after all, would have believed him? To Tiny Tim, who did go to dental school, Scrooge was like a second father. Indeed years later the practice was to become known as Scrooge, Cratchit and Marley to mark the advent of the new partner. Some people laughed to see the change in him but he let them laugh. Ever afterwards it was said of him that of all people he knew how to keep Christmas well. And so, as Tiny Tim said, 'God fill us every one.'

By Stephen Hancocks

Update from a piece published in the BDJ last century 